\title{
Integrating the pastoral component in agricultural systems
}

\author{
Paulo César de Faccio Carvalho ${ }^{1 *}$, Raquel Santiago Barro ${ }^{1}$, Armindo Barth Neto ${ }^{1}$, Pedro Arthur \\ de Albuquerque Nunes ${ }^{1}$, Anibal de Moraes ${ }^{2}$, Ibanor Anghinoni ${ }^{3}$, Christian Bredemeier ${ }^{4}$, Cimélio \\ Bayer $^{3}$, Amanda Posselt Martins ${ }^{3}$, Taise Robinson Kunrath ${ }^{1}$, Davi Teixeira dos Santos ${ }^{5}$, Felipe \\ de Campos Carmona ${ }^{6}$, Thiago Barros ${ }^{1}$, William de Souza Filho', Gleice Menezes de Almeida1, \\ Luis Augusto Martins Caetano', Diego Cecagno ${ }^{3}$, Fernando Arnuti ${ }^{3}$, Luiz Gustavo de Oliveira \\ Denardin ${ }^{3}$, João de Andrade Bonetti ${ }^{3}$, Cezar Augusto Gama de Toni ${ }^{3}$, José Bernardo Moraes \\ Borin $^{3}$
}

\footnotetext{
${ }^{1}$ Universidade Federal do Rio Grande do Sul, Departamento de Plantas Forrageiras e Agrometeorologia, Porto Alegre, RS, Brasil.

${ }^{2}$ Universidade Federal do Paraná, Departamento de Fisiologia Vegetal, Curitiba, PR, Brasil.

${ }^{3}$ Universidade Federal do Rio Grande do Sul, Departamento de Solos, Porto Alegre, RS, Brasil.

${ }^{4}$ Universidade Federal do Rio Grande do Sul, Departamento de Plantas de Lavoura, Porto Alegre, RS, Brasil.

${ }^{5}$ Serviço de Inteligência em Agronegócios, Porto Alegre, RS, Brasil.

${ }^{6}$ INTEGRAR - Gestão e Inovação Agropecuária, Porto Alegre, RS, Brasil.
}

\begin{abstract}
This paper aims to discuss the impact of the introduction of pastures and grazing animals in agricultural systems. For the purposes of this manuscript, we focus on within-farm integrated crop-livestock systems (ICLS), typical of Southern Brazil. These ICLS are designed to create and enhance the synergisms and emergent properties have arisen from agricultural areas where livestock activities are integrated with crops. We show that the introduction of the crop component will affect less the preceding condition than the introduction of the livestock component. While the introduction of crops in pastoral systems represents increasing diversity of the plant component, the introduction of animals would represent the entry of new flows and interactions within the system. Thus, given the new complexity levels achieved from the introduction of grazing, the probability of arising emergent properties is theoretically much higher. However, grazing management is vital in determining the success or failure of such initiative. The grazing intensity practiced during the pasture phase would affect the canopy structure and the forage availability to animals. In adequate and moderate grazing intensities, it is possible to affirm that livestock combined with crops (ICLS) has a potential positive impact. As important as the improvements that grazing animals can generate to the soil-plant components, the economic resilience remarkably increases when pasture rotations are introduced compared with purely agriculture systems, particularly in climate-risk situations. Thus, the integration of the pastoral component can enhance the sustainable intensification of food production, but it modifies simple, pure agricultural systems into more complex and knowledge-demanding production systems.
\end{abstract}

Key Words: grazing management, integrated crop-livestock system, sustainable intensification

\section{Introduction}

In contemporary agriculture, primary and secondary productivity are consequences of systems based on simplification, specialization, and standardization. Particularly in developing countries, improved yields are reached without taking into account neither environmental nor social impacts. The process of farm simplification and

\section{Received: January 2, 2017}

Accepted: April 8, 2017

*Corresponding author: paulocfc@ufrgs.br

Copyright @ 2018 Sociedade Brasileira de Zootecnia. This is an Open Access article distributed under the terms of the Creative Commons Attribution License (http://creativecommons.org/licenses/by/4.0/), which permits unrestricted use, distribution, and reproduction in any medium, provided the original work is properly cited. specialization that prevails in modern agriculture, promoted by the Green Revolution (Griffon, 2012), is currently associated with negative environment impacts and global warming.

The modernization pathway chosen after the II World War, also called "intensive agriculture", is based on the simplification and high input agricultural practices. Plant production has advanced, but it remains highly dependent on artificial fertilizers and pesticides, irrigation, and fossil fuels (Stoate et al., 2001). For example, in the last fifty years, the world food production increased threefold (Lemaire et al., 2015), while the nitrogen applied in agriculture increased eightfold (Subbarao et al., 2013). The remarkable decrease in nutrient use efficiency in agriculture is associated with the imminent exhaustion of plant yield gains (Foley et al., 2011). 
The incessant search for higher yields based on promiscuous input utilization promoted undesirable side effects, such as ecosystem biodiversity losses, soil deterioration, and air and water pollution, all of them largely reported in literature (Millennium Ecosystem Assessment, 2005; Russelle et al., 2007; Hannah et al., 2013; Lemaire et al., 2015). These agricultural system models are nowadays considered unacceptable by society (Lemaire et al., 2014).

Therefore, there is an urgent need for course correction, mainly changing the perspective of worldwide food production models (Carvalho, 2005). Initiatives in this sense are expanding gradually, such as no-tillage systems, crop-livestock integration, concerns about the rational use of water and agrochemicals, demands for greater competitiveness and sustainability, access to lines of credit based on environmental requirements (e.g. ABC Plan low-carbon agriculture program in Brazil), among others. These latest requirements for agricultural production systems aim to reduce costs and, at the same time, preserve the environment (Kluthcouski and Stone, 2003).

The benefits of integrating crops and livestock are supported by many recent published papers (Trayce and Zang, 2008; Bell et al., 2014; Bonaudo et al., 2014; Deiss et al., 2016), reviews (Carvalho et al., 2010; Ryschawy et al., 2014; Gastal and Lemaire, 2015; Lemaire et al., 2015), and special issues (Franzluebbers et al., 2014). The majority of these manuscripts suggests that integrated crop-livestock systems (ICLS) are capable of reconciling food production with environmental preservation.

According to Rota and Sperandini (2011), the benefits of ICLS are recapitulated in four general areas: agronomic, including the preservation and maintenance of soil productive capacity; economic, targeting the diversity of food production with safety and higher yields at lower costs; ecologic, by reducing pests, pesticide use, and better erosion control; and social, by reducing rural-urban migration with increasing new employment opportunities in rural areas. In North and Midwest Brazil, establishing crops over degraded pasturelands provides the necessary cash flow for paying the substantial investment in lime and fertilizer (Zimmer et al., 2004). On the other hand, ICLS in Southern Brazil have been used as an alternative for reducing risk associated with frequent summer crop frustrations and low winter market prices of grain crops, thus providing the potential to increase profits and land use efficiency (Carvalho et al., 2006).

The improvements brought by adopting the ICLS exceed the farm unit (within-farm scale) and reach landscape level (e.g. among farms or territories). Moraine et al. (2017) presented an elegant framework that explores this concept. Considering the difficulty to introduce grain crops on specialized livestock farms, and vice versa, the integration at landscape level can be considered an intelligent solution to resolve this trade-off. It is an alternative to the introduction of ICLS models into farms/territories that face restrictions to animal production (i.e. hilly lands or dry lands). For example, calf production based on natural grasslands at extreme Southern Brazil (Pampa biome) can supply growing and finishing steers to the Northern region of Rio Grande do Sul State (Atlantic Forest biome) for rotations of soybean and cool season pasture, so cash crop farmers can avoid dealing with cow-calf operations. Moreover, some advantages, such as reducing the occurrence of pests or diseases or increasing water quality, are more frequently reported at landscape level (Duru et al., 2015). To reach such results, it is necessary to rethink and redesign ICLS at landscape level.

Despite all potential benefits of ICLS, the introduction of grazing animals into agricultural areas leads to debate and concerns about the pasture/animal effect. Hence, this paper aimed to discuss the influence of the introduction of pastures and grazing animals into agricultural systems. For the purposes of this manuscript, we focused on withinfarm integrated crop-livestock systems typical of Southern Brazil.

\section{Conceptual diagram of including/integrating grazing animals into agricultural systems}

Integrated crop-livestock systems are designed to create and enhance the synergisms and emergent properties have arisen from agricultural areas where livestock activities are integrated with crops. According to Moraes et al. (2012), the interactions between the ICLS components (i.e. soil, trees, grains, and livestock) "require highly challenging management strategies", which are not employed in systems based on monocultures (Lin et al., 1999). The resulting effect of these interactions, at ecologic and economic levels, can be positive (favoring), neutral, or negative (competition) (Callaway and Walker, 1997) depending on the system design. As the interactions are dynamic, the effects can change from favorable to competitive, and vice versa, with interactive stages coexisting in time and space (Anderson and Sinclair, 1993). Therefore, the results obtained in complex systems, such as ICLS, cannot be interpreted by individual factors, requiring a holistic vision of this agroecosystem (Wilson and Ludlow, 1990; Nair, 1993; Ong and Leakey, 1999; Lin et al., 1999; Torquebiau, 2000; Jose et al., 2004). 
To illustrate these complex interactions, one can consider the establishment of an ICLS model in two different ways: the introduction of the animal component into a purely agricultural system or the introduction of crops into a purely pastoral system (Figure 1).

The diagram considers the plant component as pasture, grain crops, or trees, that is, any plant involved in the system. The arrows within the overlapping areas represent the interactions between components, which occur at different time scales. The shaded areas represent the mediation of the soil component. The soil is the "physical memory" of the system (Anghinoni et al., 2013); while the other components are alternated in time and space, the soil incorporates long-term consequences of succession of components and their management.

Nutrients are always cycling between the different compartments of the system. According to Soussana and Lemaire (2014), cycles of $\mathrm{C}$ and $\mathrm{N}$ are coupled according to principles of stoichiometry. The soil and plant compartments are couplers of $\mathrm{C}$ and $\mathrm{N}$ in the formation of plant biomass and organic matter. The animal compartment, in turn, decouples $\mathrm{C}$ and $\mathrm{N}$ by the grazing process, for example, releasing enteric methane and $\mathrm{N}$ into the excreta generated

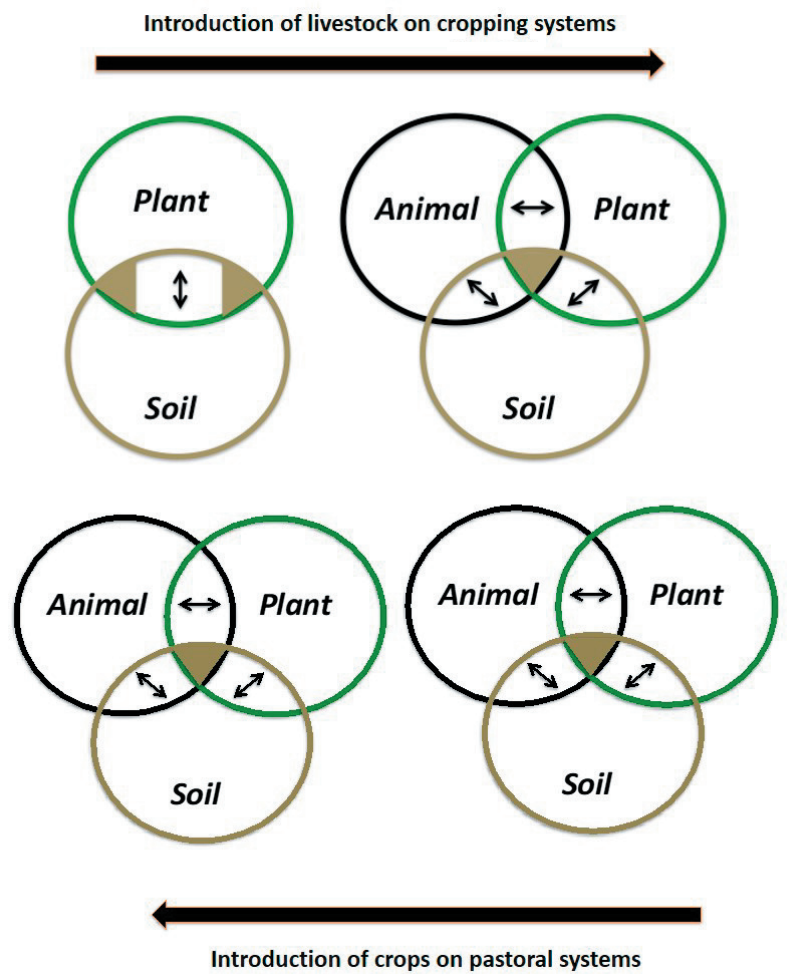

Figure 1 - Conceptual diagram of soil-plant and soil-plant-animal relationships in production systems that integrate the animal component into purely agricultural systems or integrate the crop component into purely pastoral systems (Carvalho et al., 2015) by plant biomass intake. The balance between compartments depends critically on grazing intensity (Carvalho et al., 2010; Soussana and Lemaire, 2014). Moderate grazing intensities favor the coupling between $\mathrm{C}$ and $\mathrm{N}$ by cycling $\mathrm{N}$ via urine, stimulating leaf area renewal and favoring rhizodeposition by grazing, often related to increases in soil C stocks (Balesdent and Balabane, 1996). However, at high grazing intensities, decoupling is greater than coupling and the system balance is negative. Therefore, the management of nutrient flows between compartments by controlling the coupling and decoupling processes is essential to obtain positive results in ICLS.

From the viewpoint of system operation, it can be inferred that the introduction of the crop component will affect less the preceding condition than the introduction of the livestock component (Figure 1). While the introduction of crops into pastoral systems represents increasing diversity of the plant component, the introduction of animals would represent the entry of new flows and interactions within the system. According to Bonaudo et al. (2014), the animal role is to recycle and increase the use efficiency of resources. Thus, given the new complexity levels achieved from the introduction of grazing, the probability of arising emergent properties (Anghinoni et al., 2013) is theoretically much higher.

The interactions between components can occur at distinctive spatial and temporal scales. For example, when the plant component is a pasture, the interaction with the animal component is direct and immediate by grazing, excreta deposition, and trampling. When the plant component is a crop in succession, then the time scale is shifted to the period equivalent to the rotation and the interaction is mediated, for example, by dung residue from the pasture phase. Given that grazing animals have such an important influence on the efficiency and functioning of ICLS, we focus now on the particular influences of grazing on ICLS.

\section{The grazing process and characteristics inherent to the integrated crop-livestock systems}

Grazing is an intricate process by which herbivores seek their food. It is characterized by the actions of the animal in the search, selection, and apprehension of forage, in which the bite is the climax event and results from a complex series of decisions made by the animal. Among them, the most relevant are the definition of the feeding site within the pasture, the species to be consumed within the chosen site, and the definition of which parts of the plants should be consumed (Carvalho and Moraes, 2005). 
These decisions end up influencing the way the animal moves throughout the pasture, as well as the intensity by which it uses pastures, two aspects of superlative importance for ICLS. The first determines the phenomena of soil compaction. The second affects $\mathrm{C}$ and $\mathrm{N}$ coupling and the amount of residue for cropping under no-tillage. In this sense, to control the effect of grazing animals on these systems, it is important to understand the nature of the processes within the ICLS.

Therefore, the discussion of such issues is proposed from a conceptual diagram of the grazing process in the context of ICLS (Figure 2).

The conceptual diagram is based on a typical ICLS model from Southern Brazil, which integrates rotating crops and pastures in the same area. It suggests that grazing intensity practiced during the pasture phase would affect the canopy structure and the forage availability to animals. At high grazing intensities, the production of the pasture phase is affected by low herbage mass, which in turn determines both primary (biomass accumulation rates) and secondary (animal performance) production decline. The accumulation rates depend on the herbage mass, as it determines the leaf area index and light interception, both directly related to forage mass (Silva and Pedreira, 1997). Regarding animal production, herbage mass affects dry matter intake through bite mass. This consequently affects the individual animal performance and the live weight gain per unit area.
The relationships between grazing intensity and herbage mass that determine animal performance described above are classic plant-animal interactions of pastoral systems. This phase is connected to crop phase by the residual herbage mass (and animal excreta), which constitutes the structure that receives crop seeds under notillage, representing an important management action to the subsequent cultivation. The higher the grazing intensity, the lower the residual biomass at the time of crop sowing and the higher the compaction transferred to the crop phase (Carvalho et al., 2011). Moreover, under high grazing intensities, nutrient decoupling is higher than coupling, as previously mentioned. This entire context finally determines the soil chemical, physical, and biological environment that receives the crop.

Residues from the pasture phase affect the succeeding crop, as the amount (quantity) and the nature (quality) of these residues define nutrient releasing rates from pasture biomass into the crop. Grazing itself directly influences the vegetation properties and the heterogeneity intrinsic to the ICLS. Moderate to light grazing intensities increase vegetation spatial heterogeneity, which becomes higher with decreasing grazing intensities (Figure 3 ). The use of higher grazing intensities leads to spatially homogeneous canopy throughout the pasture phase, characterized mostly by excessively grazed vegetation with usual occurrence of bare soil. Furthermore, pasture cover at the end of the pasture phase affects weed infestation in the subsequent

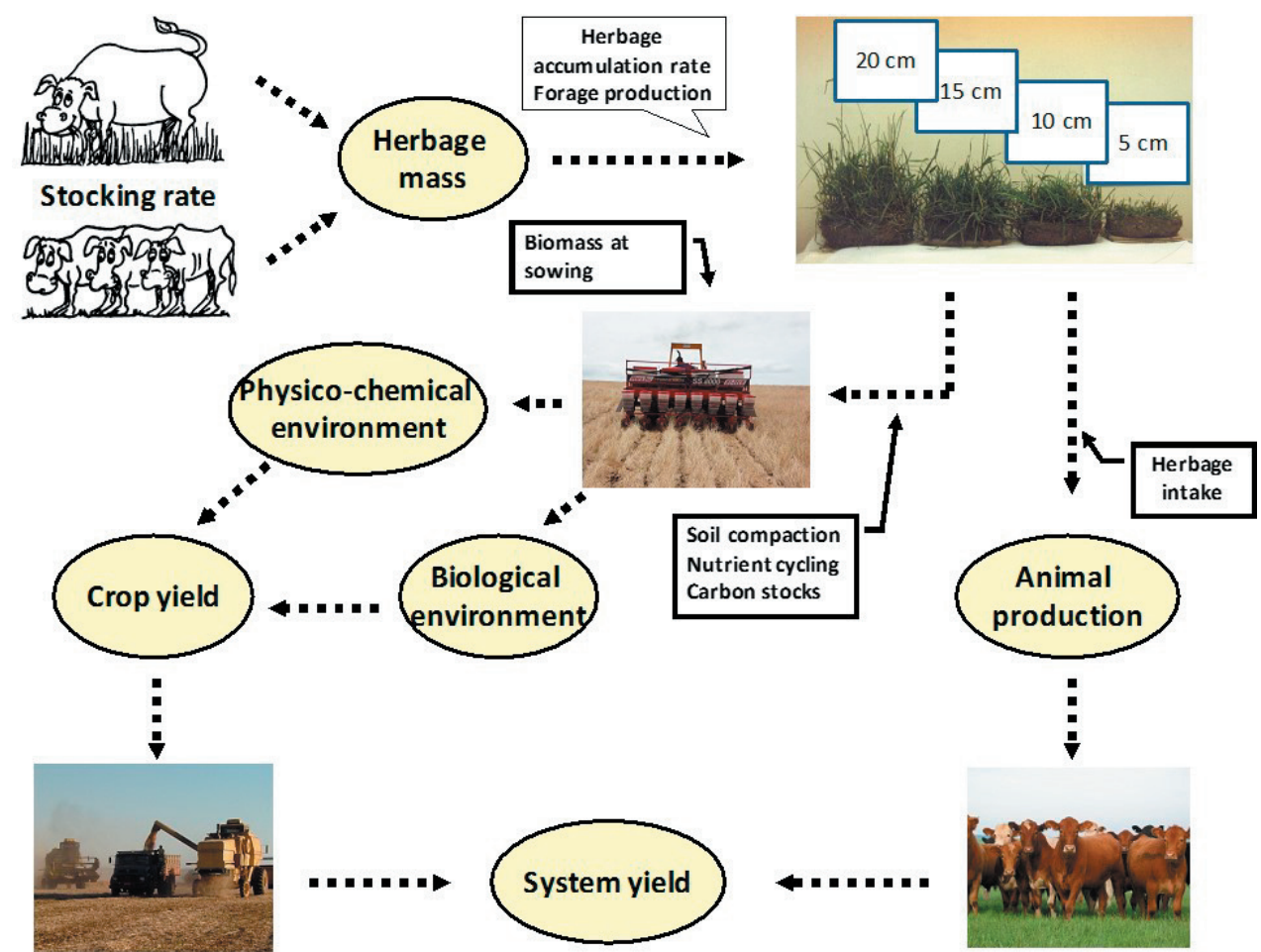

Figure 2 - Conceptual diagram of how grazing intensity affects the integrated crop-livestock system (adapted from Carvalho et al., 2010). 
crop, since the lower the residual biomass covering the soil, the higher the incidence of weeds (Kunrath et al., 2015).

Another factor associated with the residual biomass covering soil surface is soil moisture. The lower the residual biomass, the lesser is the soil ability to retain water. In addition, the excreta of animals are transferred to the crop phase creating a more uneven spatial distribution of the nutrients.

After the cultivation of grain crops, a new pasture phase returns over crop residues and then crops affect pasture establishment (Crusciol et al., 2012; Barth Neto et al., 2014). After 15 years of soybean-pasture integration, the sward structure at the beginning of the pasture phase suggests that soybean rotations buffer the heterogeneity created by the animals during the grazing period (Figure 3a). However, Barth Neto et al. (2014) identified an effect of grazing along different grazing seasons (Figure 4).

The authors identified a tendency to lower sward heights over the years (2010 to 2012) at the beginning of the pasture phase, when pasture was managed under higher grazing intensities in the previous years of self-seeding Italian ryegrass pastures. In this case, the grazing intensity would affect pasture seed production. Higher grazing intensities (e.g. lower sward height) can have negative consequences on seed head production (Evers and Nelson, 2000), thus affecting the ability for natural self-seeding of

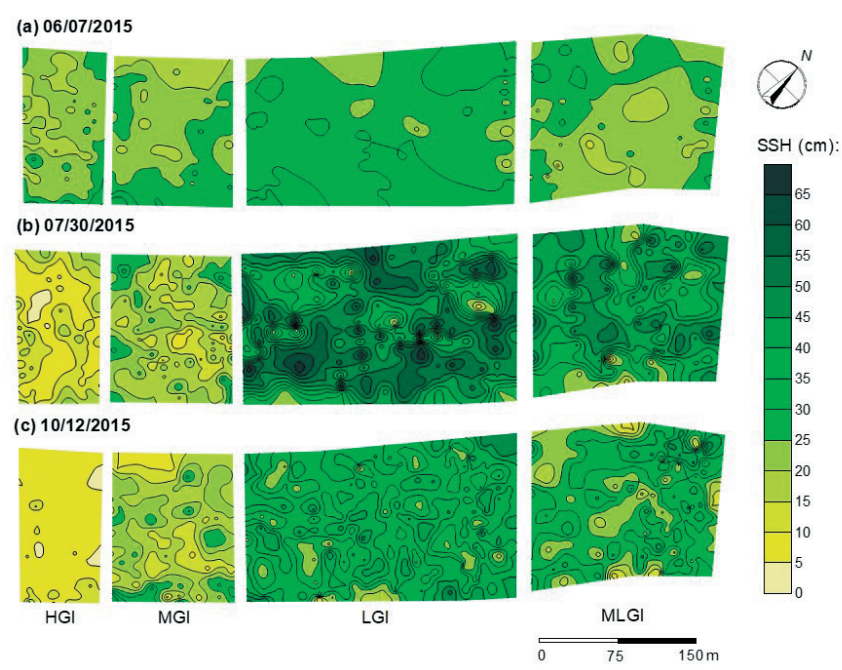

HGI - high grazing intensity, average $\mathrm{SSH}=10 \mathrm{~cm}$; MGI - moderate grazing intensity, average SSH $=20 \mathrm{~cm}$; MLGI - moderate-light grazing intensity, average $\mathrm{SSH}=30 \mathrm{~cm}$; and LGI - light grazing intensity, average $\mathrm{SSH}=40 \mathrm{~cm}$.

Figure 3 - Distribution of georeferred sward surface height ( $\mathrm{SSH}$, $\mathrm{cm}$ ) along paddocks under different grazing intensities by steers on Italian ryegrass (Lolium multiflorum Lam.) and black oat (Avena strigosa Schreb.) mixed swards (a) before grazing, (b) at higher vegetation spatial heterogeneity, and (c) at the end of the pasture phase (adapted from Nunes, 2016). the pasture in the forthcoming years (Bartholomew and Williams, 2009; Barth Neto et al., 2014). Thus, managing pasture under higher grazing intensities could result in the necessity of reseeding, in addition to the natural selfseeding process.

Crops and pastures may succeed in many possible time and space arrangements. The only long-lasting component of the system is the soil, which in the long term incorporates all the effects from management and rotations and represents the "connectivity" between temporally apart components (e.g. urine spots from pasture phase influencing yield of succeeding maize). For this reason, Anghinoni et al. (2013) considered the soil as the "memory of the system", because it converges all these effects on chemical, physical, and biological attributes.

\section{Integrating grazing into agricultural systems}

The above items showed the importance of grazing intensity in defining ICLS success or failure. To move forward on this issue, we addressed in detail some examples of how grazing intensity affects the soil and plant components of the system.

The herbage mass along the pasture phase sets the pattern of forage apprehension by the grazing animal, by affecting how often the animal performs bites (Carvalho et al., 2005). In general, a greater frequency of bites is required at lower herbage mass. Indeed, herbage mass also affects other parameters associated with forage acquisition rate.

According to Carvalho (2005), forage allowance defines the particular dynamic of the meal cycles over

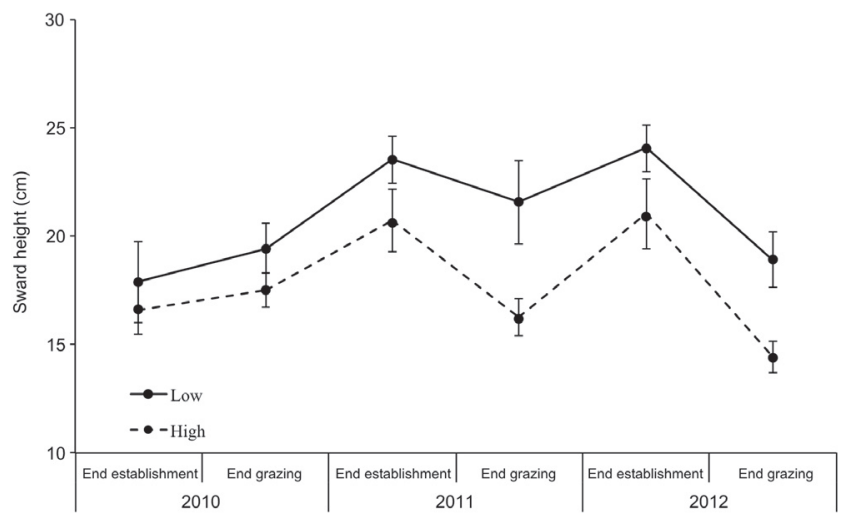

Figure 4 - Italian ryegrass sward heights at the beginning and end of pasture phase (2010, 2011, and 2012). Values represent the means and standard deviation of sward height according to grazing intensities (low and high) (adapted from Barth Neto et al., 2014). 
time. The number and size of each cycle reflects the satiety level reached by the animal. The lower this level (limiting herbage mass situations), the longer the time spent in the feeding process and the displacement time searching for food and the higher the number of visited feeding stations (Figure 5).

The results show that time spent on grazing is a direct function of herbage mass and animals could increase grazing time by $50 \%$ at low herbage mass or sward surface height. In such circumstances, the animal grazes for longer periods, seeking to maintain the daily intake at satisfactory levels. The increase in daily grazing time is achieved both by increasing the average time of the meal duration and decreasing the interval between meals (Carvalho, 2005).

The increasing grazing time and the time spent searching for forage escalates the effect of the animal. Pasture restrictions do not merely increase grazing time, but also increase the moving rate (Baggio et al., 2009), meaning that animals increase the number of steps taken per unit time in an attempt to find more forage to consume. The final result is that the total number of steps increases by nearly $100 \%$ when compared with non-limiting situations (Figure 5).
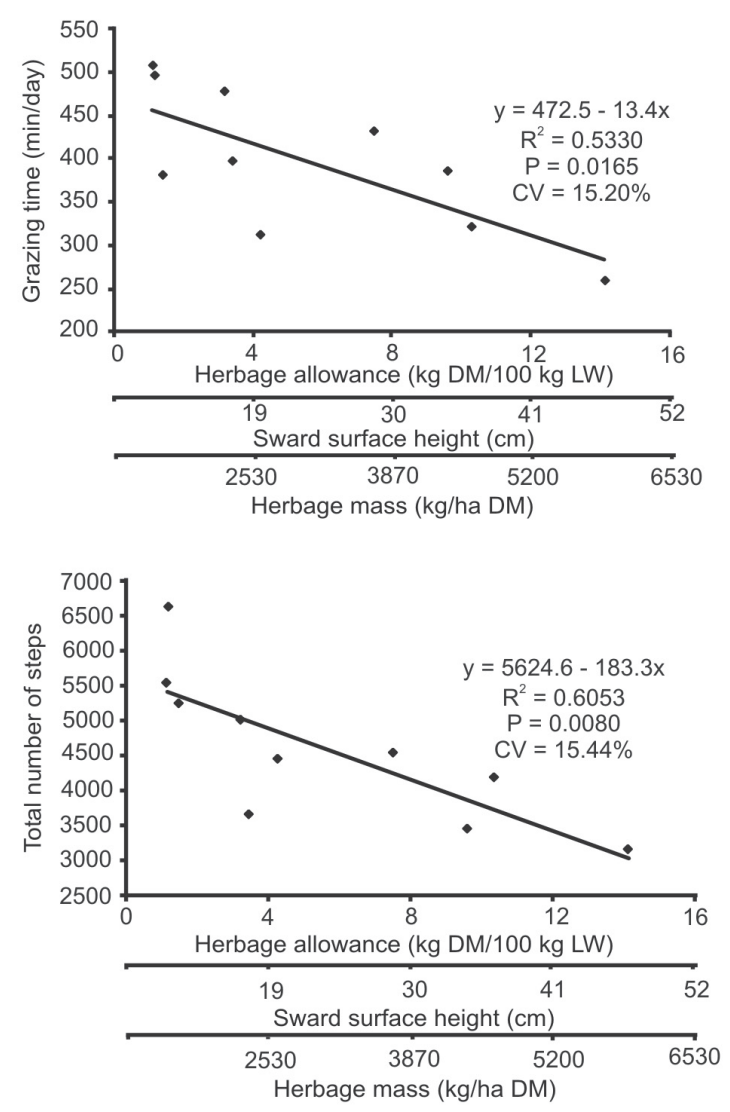

The feeding stations are like "forage dishes", by definition meaning the area reached by the grazing animal without moving its forelegs. The greater the quantity of nutrients in the feeding station, the longer the animal residence time. The time spent exploring the feeding station is directly related to the amount of standing forage. The lower this quantity, the sooner the animal is forced to abandon that feeding station and select a new one. Consequently, the number of visited feeding stations increases in herbagelimiting situations (Figure 5). Therefore, the animal is forced to walk faster, increasing energy expenditure and jeopardizing performance. The crop phase can be negatively affected because increasing displacement means increasing number of impacts of the hoof on the soil and extension of the area potentially damaged by compaction (Figure 6).

The results illustrate the convergent effect of different behavioral parameters affected by management that determines the ultimate effect of the grazing animals. At high grazing intensities, not only individual animals walk more, but the group of animals is bigger, causing the physical area of soil affected by the animals to become three times larger.

Carvalho et al. (2011) compiled data of soil physical properties after 10 years of a long-term ICLS experiment.
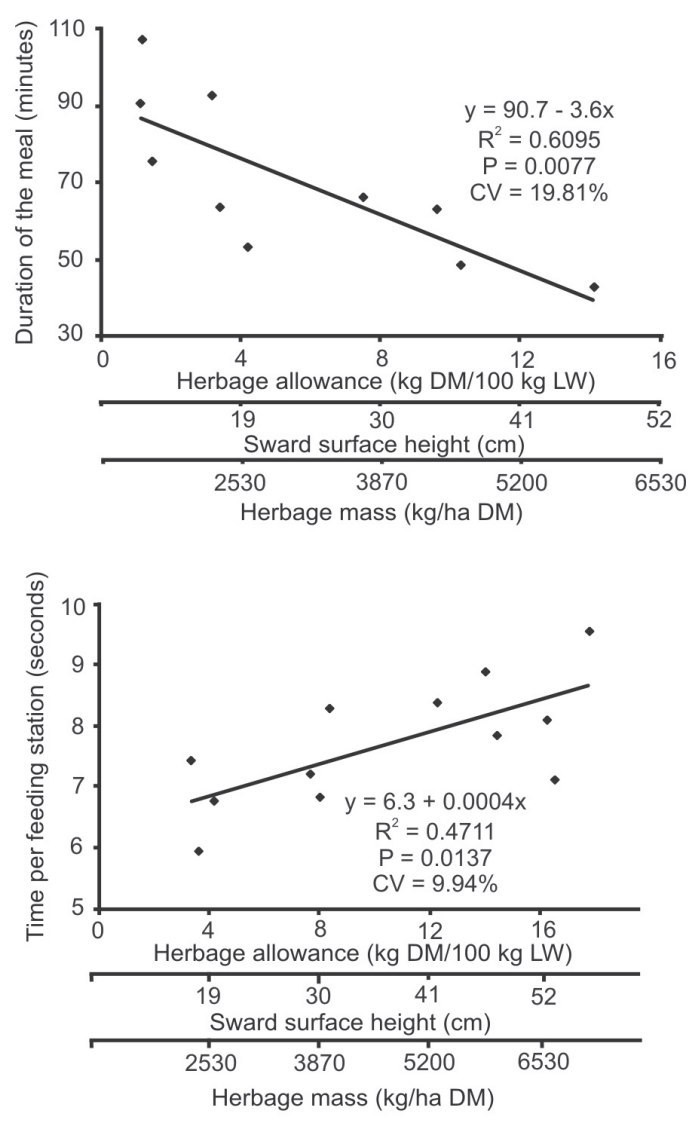

$\mathrm{R}^{2}$ - coefficient of determination; CV - coefficient of variation; DM - dry matter.

Figure 5 - Characteristics of the grazing process of steers within an integrated crop-livestock system (data calculated from Baggio et al. 2009). 

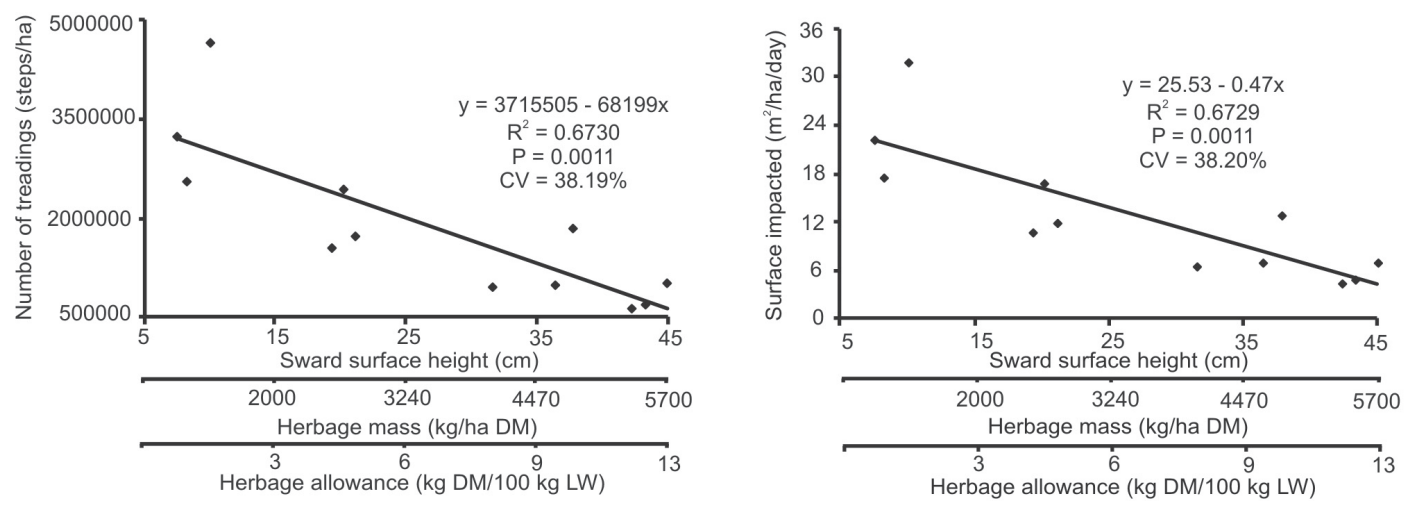

$\mathrm{R}^{2}$ - coefficient of determination; CV - coefficient of variation; DM - dry matter; LW - live weight.

Figure 6 - Patterns of steer displacement according to pasture characteristics along the pasture phase of an integrated crop-livestock system. Data calculated from Baggio et al. (2009) considering the impact area of $90 \mathrm{~cm}^{2} /$ hoof as suggested by Di et al. (2001). The data refers only to the diurnal displacement.

Despite being a dark-red clayey Oxisol (Rhodic HapludoxSoil) with clay contents of $0.54 \mathrm{~kg} / \mathrm{kg}$ of soil, it was observed that soil compaction only occurred at high grazing intensities, but did not affect the yield of the succeeding crop. More than occurring only on the superficial soil layer $(0-5 \mathrm{~cm})$, compaction in the higher grazing intensity treatments was reversed by cropping soybeans in every succession cycle. Bell et al. (2011) reviewed soil damage caused by livestock in cropped areas and concluded that the effects are limited to the soil surface and are short-lived. Indeed, where current best-practice grazing management occurs, such impacts are unlikely. The aggregation state, which is one of the most important attributes of soil quality, is favored by moderate grazing on both the surface and deeper layers. According to Carvalho et al. (2011), organic deposition promotes particle aggregation, acting as cementing agent between the soil particles.

From a chemical perspective, the effect of the animal, when comparing purely agricultural areas with integrated areas, is striking (Figure 7).

All the chemical characteristics are favored by animal grazing. There is translocation of fine particles from upper to deeper soil layers in grazed areas, by biopores or soil macropores. The animal effect is also observed by the reduction in the acidity of organic acids of low molecular weight released by the decomposition of excreta associated to the exudation of organic compounds by the roots along the pasture phase (Carvalho et al., 2011).

Assmann et al. (2014) investigated the influence of rotating pastures with soybean crops on $\mathrm{C}$ and $\mathrm{N}$ stocks in particulate fractions and associated minerals into the soil. The authors concluded that high grazing intensities decreased the levels of $\mathrm{C}$, total $\mathrm{N}$, and organic particulates,

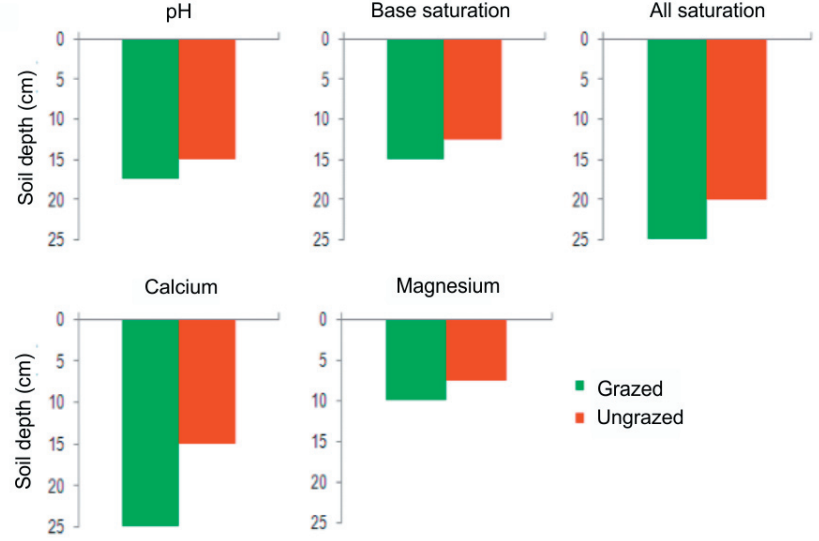

Figure 7 - Maximum depth of soil correction after surface liming in different acidity attributes in integrated (grazed) and non-integrated (ungrazed) areas, 24 months after liming (Carvalho et al., 2011).

compared with ungrazed areas. High grazing intensities led to a loss of $\mathrm{N}$, in the order of $1.17 \mathrm{Mg} \mathrm{ha}^{-1}$ due to organic matter degradation. The annual soil $\mathrm{C}$ addition was smaller for high grazing intensity $\left(3.65 \mathrm{Mg} \mathrm{ha}^{-1}\right)$ compared with areas without grazing and under light and moderate grazing intensities (between 20 to $40 \mathrm{~cm}$ sward surface height, 4 . $\left.74 \mathrm{Mg} \mathrm{ha}^{-1}\right)$.

Another important effect of grazing animals on agricultural rotations is the influence on microbial biomass and diversity. The former responds positively and linearly to grazing intensity, while the second has a curvilinear response (Carvalho et al., 2011), meaning that moderate grazing intensities favor the diversity of microbiota (Chávez et al., 2011).

Briefly, the incorporation of pastures into agricultural systems can generate positive or negative effects depending 
on grazing intensity. There is a good chance of improving soil chemical, physical, and biological properties under moderate grazing intensities. However, system performance also depends on grain production; therefore, we address now some results related to the influence of pasture phase on succeeding crop yield.

\section{Influence of integrating pastures (and grazing animals) on crop productivity}

The main stocking methods used by the ICLS are the continuous and the rotational stocking. The animals remain in the same pasture for a long period under continuous stocking. On the other hand, the paddock is divided into several smaller units and animals rotate along different subdivisions in preset stocking cycles (occupation periods + resting periods) under rotational stocking.

Both methods have several variations, but the fundamental difference between them lies in the spatiotemporal control of the grazing process. From the spatial perspective, while rotational stocking looks at homogeneously distributed grazing, forcing the animals to explore the whole paddock along the stocking cycle, the continuous stocking has slight control over the distribution of animals and allows them to explore the pasture according to their choices.

Although there is reasonable agreement in the scientific community that regardless of the stocking method, the results regarding animal production are very similar when using appropriate grazing intensities (Briske et al., 2008), the influence of stocking methods on ICLS is poorly understood. To illustrate this issue, we address an ICLS model designed for smallholders, in which the pasture phase aims to raise lambs succeeded by soybean or corn in rotation (Figure 8).
Results illustrate the predominant effect of grazing intensities over grazing methods. It is noteworthy that treatments with higher herbage allowance, where higher forage mass permanently covers the soil, registered higher soybean yields. Although considering a single year effect, when the maize was utilized in rotation, the effect of intensities and methods is less evident, but still suggests higher yields when pasture was managed under continuous stocking with high herbage allowance (C5.0). It is worth highlighting that non-grazed areas, where vegetation serves the only purpose of producing straw for no-tillage in succession, do not produce more than grazed areas. The presence of grazing animals in no-tillage systems is still a paradigm; thus, these results are important to demonstrate that moderate grazing does not cause losses to the crops in rotation.

The major paradigm of ICLS is where crops succeeding grazed areas produce equally or more compared with the areas without grazing in the preceding season. Attempting to present insights on this debate, we revisited and updated the review of Moraes et al. (2014). Comparisons were restricted to the subtropical Brazilian region. In addition, we selected experiments with the following requirements: same cover preceding crops (forages as cover crop or to be grazed); rigorous control of grazing intensity; use of best-practice grazing management; and use of bestpractice conservation agriculture (i.e. no-tillage, except for irrigated rice) (Figure 9).

The majority of results indicates that the "dilemma of grazing" does not make sense. Crop succeeding sound grazed areas do not yield less than non-grazed areas. On the contrary, crop yield increased by $3.4,4.7,10.4$, and $10.8 \%$ on average, for soybean, bean, irrigated rice, and maize, respectively. It is worth noting that grasses apparently respond better than legumes, suggesting that nitrogen
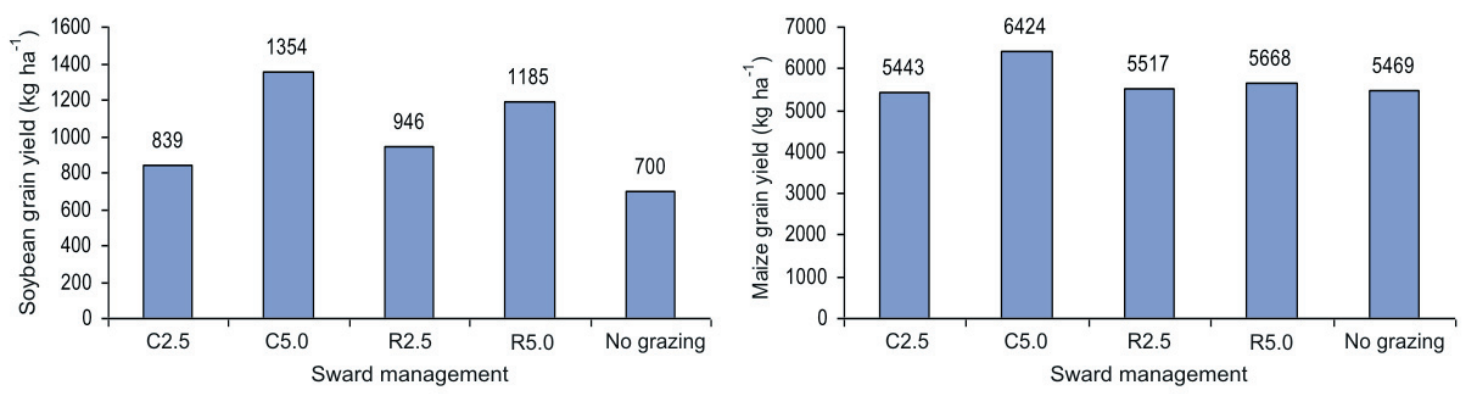

Figure 8 - Effect of grazing intensities and stocking methods along the pasture phase on corn or soybean yield under ICLS models designed for smallholders. Soybean results refer to an average of four years, while those for corn refer to a single year succession. Letters $\mathrm{C}$ and $\mathrm{R}$ refer to continuous and rotational stocking, respectively, while numerals indicate levels of herbage allowance of 2.5 or 5.0 times the potential of animal intake (adapted from Carvalho et al., 2010). 


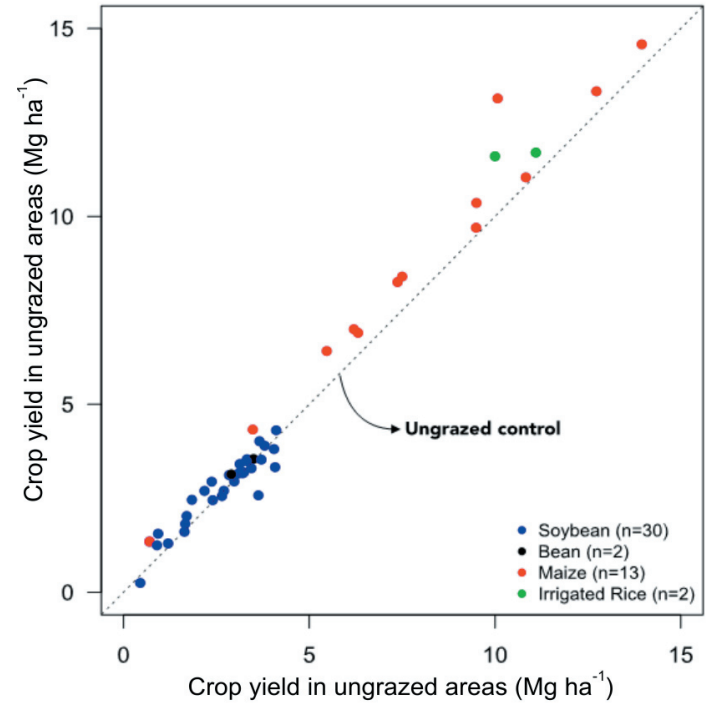

Figure 9 - Crop yield in grazed areas compared with non-grazed areas in Brazilian subtropics (Updated from Moraes et al., 2014). Data are from Ruedell (1996), Lustosa (1998), Assmann et al. (2003), Freitas (2003), Siqueira Jr. (2005), Freitas (2008), Lunardi et al. (2008), Carvalho et al. (2010), Bartmeyer et al. (2011), Macari et al. (2011), Sandini et al. (2011), Sartor et al. (2012), Silva et al. (2012), Silveira et al. (2012), Andreolla et al. (2014), Andreolla et al. (2015), Ferreira et al. (2015), Franchini et al. (2015), Kunrath et al. (2015), Barros (2016), and Silva (2016).

cycling by grazing animals could be the prevailing factor determining differences, as legumes count on biological nitrogen fixation inputs. This is a hypothesis to be confirmed. Moreover, these very rare data are helpful to distinguish the forage-crop rotation effect from the grazing animal effect, because all data from the ungrazed control was from forage crops preceding grain crops; thus, the only effective difference was animal grazing.

This synthesis counteracts the prevailing paradigm, according to which animals grazing no-tillage areas in rotation with agriculture would influence the subsequent crop adversely. There are numerous evidences that animal benefits the system and not the opposite (e.g. George et al., 2013; Franzluebbers and Stuedemann, 2014). However, sound grazing management is essential to reach positive results (Carvalho et al., 2010).

As important as the improvements that grazing animals can generate to the soil-plant components, the economic resilience increases remarkably when pasture rotations are introduced compared with purely agriculture systems, particularly in climate risk situations (Figure 10).

Results illustrate the benefits that integration of a pasture phase may generate to the farming operation. In this example, soybean is cultivated in spring/summer

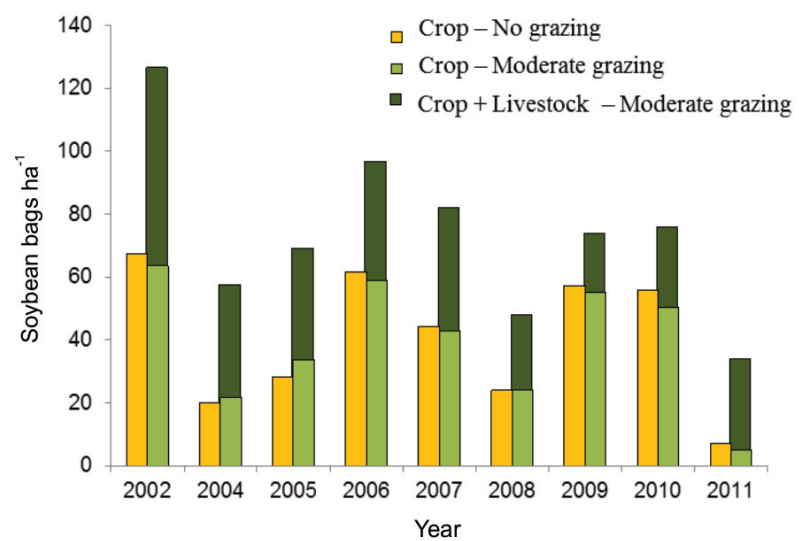

Figure 10 - Soybean yield succeeding grazed or ungrazed areas. Secondary production from the pasture phase (steers live weight gain $\mathrm{kg} \mathrm{ha}^{-1}$ ) were transformed into equivalent soybean bags (60 kg of grain - $13 \%$ humidity) by relative soybean and meat prices from each year (adapted from Carvalho et al., 2011).

and droughts occur occasionally. Ryegrass-oat mixtures are cultivated in autumn/winter and unfavorable weather conditions rarely occur. Consequently, uncertainty concerns more the crop phase than the pasture phase. Between 2002 and 2011, soybean yield (yellow bars) from ungrazed areas varied between 5 and 70 bags $\mathrm{ha}^{-1}$. In general, the costs of cropping, expressed as equivalent soybean bags, varied between 25 and 30 bags ha $^{-1}$. Light green bars are soybean yield succeeding grazed areas and dark green bars are the pasture phase yields (steers live weight gain $\mathrm{kg} \mathrm{ha}^{-1}$ ) transformed into equivalent soybean bags to express yield of a unit of land in the same output unit. Pure soybean system produced, on average, $49 \mathrm{bags} \mathrm{ha}^{-1}$, while the integration of soybean and beef cattle produces the equivalent of 81 bags $\mathrm{ha}^{-1}$ (Carvalho et al., 2011). In addition to the higher profitability achieved under ICLS, it is crucial to emphasize the resilience role of an additional pasture yield in years of crop frustration. It is the pasture component (i.e. grazing animals) that generates security to agricultural practice. As it can be noticed, ICLS productivity is superior to the combined individual incomes of pure systems.

\section{Conclusions}

Livestock combined with crops has a potential postive impact. Grazing management is vital in determining the success or failure of such initiative. Apparently, the choice of the grazing method does not have such meaning.

The integration of the pastoral component can enhance the sustainable intensification of food production, but it modifies simple, pure agricultural systems into more complex and knowledge-demanding production systems. 


\section{References}

Anderson, L. S. and Sinclair, F. L. 1993. Ecological interactions in agroforestry systems. Forestry Abstracts 54:489-523.

Andreolla, V. R. M.; Moraes, A.; Bonini, A. K.; Deiss, L. and Sandini, I. E. 2014. Soil physical attributes in integrated bean and sheep system under nitrogen levels. Revista Ciência Agronômica 45:922-930.

Andreolla, V. R. M.; Moraes, A.; Bona Filho, A.; Cardoso, D. L.; Oliveira, E. B. and Bonini, A. K. 2015. Pastejo e adubação nitrogenada sobre os atributos físicos do solo em sistema de integração lavoura-pecuária. Engenharia Agrícola 35:1019-1031.

Anghinoni, I.; Carvalho, P. C. F. and Costa, S. E. V. G. A. 2013. Abordagem sistêmica do solo em sistemas integrados de produção agrícola e pecuária. p.325-380. In: Tópicos em ciências do solo. Araújo, A. P. and Alves, B. J. R., eds. Sociedade Brasileira de Ciência do Solo, Viçosa, MG, Brazil.

Assmann, T. S.; Ronzelli Jr., P.; Moraes, A.; Assmann, A. L.; Koehler, H. S. and Sandini, I. 2003. Rendimento de milho em área de integração lavoura-pecuária sob o sistema plantio direto, em presença e ausência de trevo branco, pastejo e nitrogênio. Revista Brasileira de Ciência do Solo 27:675-683.

Assmann, J. M.; Anghinoni, I.; Martins, A. P.; Costa, S. E. V. G. A.; Cecagno, D.; Carlos, F. S. and Carvalho, P. C. F. 2014. Soil carbon and nitrogen stocks and fractions in a long-term integrated croplivestock system under no-tillage in southern Brazil. Agriculture, Ecosystems \& Environment 190:52-59.

Baggio, C.; Carvalho, P. C. F.; Silva, J. L. S.; Anghinoni, I.; Lopes, M. L. T. and Thurow, J. M. 2009. Padrões de deslocamento e captura de forragem por novilhos em pastagem de azevémanual e aveia-preta manejada sob diferentes alturas em sistema de integração lavoura-pecuária. Revista Brasileira de Zootecnia 38:215-222.

Balesdent, J. and Balabane, M. 1996. Major contribution of roots to soil carbon storage inferred from maize cultivated soils. Soil Biology \& Biochemistry 28:1261-1263.

Barros, T. 2016. Pastos hibernais e pastejo animal como forma de inserir diversidade e sustentabilidade ao ambiente de terras baixas do sul do Brasil. Tese (D.Sc.). Universidade Federal do Rio Grande do Sul, Porto Alegre.

Barth Neto, A.; Savian, J. V.; Schons, R. M. T.; Bonnet, O. J. F.; Canto, M. W.; Moraes, A.; Lemaire, G. and Carvalho, P. C. F. 2014. Italian ryegrass establishment by self-seeding in integrated crop-livestock systems: Effects of grazing management and crop rotation strategies. European Journal of Agronomy 57:77-83.

Bartholomew, P. W. and Williams, R. D. 2009. Establishment of Italian ryegrass (Lolium multiflorum Lam.) by self-seeding as affected by cutting date and degree of herbage removal in spring in pastures of the southern Great Plains of the United States. Grass and Forage Science 64:177-186.

Bartmeyer, T. N.; Dittrich, J. R.; Silva, H. A.; Moraes, A.; Piazzetta, R. G.; Gazda, T. L. and Carvalho, P. C. F. 2011. Trigo de duplo propósito submetido ao pastejo de bovinos nos Campos Gerais do Paraná. Pesquisa Agropecuária Brasileira 46:1247-1253.

Bell, L. W.; Kirkegaard, J. A.; Swan, A.; Hunt, J. R.; Huth, N. I. and Fettell, N. A. 2011. Impacts of soil damage by grazing livestock on crop productivity. Soil and Tillage Research 113:19-29.

Bell, L. W.; Moore, A. D. and Kirkegaard, J. A. 2014. Evolution in crop-livestock integration systems that improve farm productivity and environmental performance in Australia. European Journal of Agronomy 57:10-20.

Bonaudo, T.; Bendahan, A. B.; Sabatier, R.; Ryschawy, J.; Bellon, S.; Leger, F.; Magda, D. and Tichit, M. 2014. Agroecological principles for the redesign of integrated crop-livestock systems. European Journal of Agronomy 57:43-51.
Briske, D. D.; Derner, J. D.; Brown, J. R.; Fuhlendorf, S. D.; Teague, W. R.; Havstad, K. M.; Gillen, R. L.; Ash, A. J. and Willms, W. D. 2008. Synthesis Paper Rotational grazing on rangelands: Reconciliation of perception and experimental evidence. Rangeland Ecology \& Management 61:3-17.

Callaway, R. M. and Walker, L. R. 1997. Competition and facilitation: A synthetic approach to interactions in plant communities. Ecology 78:1958-1965.

Carvalho, P. C. F. 2005. O manejo da pastagem como gerador de ambientes pastoris adequados à produção animal. p.7-32. In: Anais do $22^{\circ}$ Simpósio sobre Manejo da Pastagem. Teoria e prática da produção animal em pastagens. Piracicaba.

Carvalho, P. C. F. and Moraes, A. 2005. Comportamento ingestivo de ruminantes: bases para o manejo sustentável do pasto. p.1-20. In: Anais do $1^{\circ}$ Manejo Sustentável em Pastagem, Maringá.

Carvalho, P. C. F.; Moraes, A.; Anghinoni, I.; Lang, C. R.; Silva, J. L. S.; Sulc, R. M. and Tracy, B. F. 2006. Manejo da integração lavoura-pecuária para a região de clima subtropical. p.177-184. In: Encontro Nacional de Plantio Direto na Palha, Integrando Agricultura, Pecuária e Meio Ambiente. FEBRAPD, Uberaba.

Carvalho, P. C. F.; Anghinoni, I.; Moraes, A.; Souza, E. D.; Sulc, R. M.; Lang, C. R.; Flores, J. P. C.; Terra Lopes, M. L.; Silva, J. L. S.; Conte, O.; Lima Wesp, C.; Levien, R.; Fontaneli, R. S. and Bayer, C. 2010. Managing grazing animals to achieve nutrient cycling and soil improvement in no-till integrated systems. Nutrient Cycling in Agroecosystems 88:259-273.

Carvalho, P. C. F.; Anghinoni, I.; Kunrath, T. R.; Martins, A. P.; Costa, S. E. V. G. A.; Silva, F. D.; Assmann, J. M.; Lopes, M. L. T.; Pfeifer, F. M.; Conte, O. and Souza, E. D. 2011. Integração sojabovinos de corte no Sul do Brasil. UFRGS, Porto Alegre. (Boletim técnico).

Carvalho, P. C. F.; Moraes, A.; Anghinoni, I.; Silva, D. T.; Kunrath, T. R.; Barro, R. S.; Carmona, F. C.; Barth Neto, A.; Martins, A. P.; Barros, T. and Filho, W. S. 2015. Integração do componente

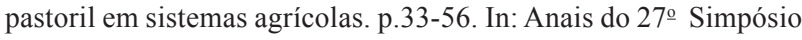
sobre Manejo da Pastagem. Sistemas de Produção, Intensificação e Sustentabilidade da Produção Animal. Da Silva, S. C.; Pedreira, C. G. S. and Moura, J. C., eds. Fealq, Piracicaba.

Chávez, L. F.; Escobar, L. F.; Anghinoni, I.; Carvalho, P. C. F. and Meurer, E. J. 2011. Diversidade metabólica e atividade microbiana no solo em sistema de integração lavoura-pecuária sob intensidades de pastejo. Pesquisa Agropecuária Brasileira 46:1254-1261.

Crusciol, C. A. C.; Mateus, G. P.; Nascente, A. S.; Martins, P. O.; Borghi, E. and Pariz, C. M. 2012. An innovative crop-forage intercrop system: Early cycle soybean cultivars and palisadegrass. Agronomy Journal 104:1085-1095.

Deiss, L.; de Moraes, A.; Dieckow, J.; Franzluebbers, A. J.; Gatiboni, L. C.; Sassaki, G. L. and Carvalho, P. C. F. 2016. Soil phosphorus compounds in integrated crop-livestock systems of subtropical Brazil. Geoderma 274:88-96.

Di, H. J.; Cameron, K. C.; Milne, J.; Drewry, J. J.; Smith, N. P.; Hendry, T.; Moore, S. and Reijnen, B. 2001. A mechanical hoof for simulating animal treading under controlled conditions. New Zealand Journal of Agricultural Research 44:111-116.

Duru, M.; Moraine, M. and Therond, O. 2015. An analytical framework for structuring analysis and design of sustainable ruminant livestock systems. Animal Frontiers 5:6-13.

Ferreira, G. A.; Oliveira, P. S. R.; Alves, S. J. and Costa, A. C. T. 2015. Soybean productivity under different grazing heights of Brachiaria ruziziensis in an integrated crop-livestock system. Revista Ciência Agronômica 46:755-763.

Foley, J. A.; Ramankutty, N.; Brauman, K. A.; Cassidy, E. S.; Gerber, J. S.; Johnston, M.; Mueller, N. D.; O’Connell, C.; Ray, D. K.; West, P. C.; Balzer, C.; Bennett, E. M.; Carpenter, S. R.; Hill, J.; 
Monfreda, C.; Polasky, S.; Rockström, J.; Sheehan, J.; Siebert, S.; Tilman, D. and Zaks, D. P. M. 2011. Solutions for a cultivated planet. Nature 478:337-342.

Franchini, J. C.; Balbinot Junior, A. A.; Debiasi, H. and Conte, O. 2015. Desempenho da soja em consequência de manejo de pastagem, época de dessecação e adubação nitrogenada. Pesquisa Agropecuária Brasileira 50:1131-1138.

Franzluebbers, A. J.; Lemaire, G.; Carvalho, P. C. F.; Sulc, R. M. and Dedieu, B. 2014. Toward agricultural sustainability through integrated crop-livestock systems: Environmental outcomes. Agriculture Ecosystems \& Environment 190:1-3.

Franzluebbers, A. J. and Stuedemann, J. A. 2014. Crop and cattle production responses to tillage and cover crop management in an integrated crop-livestock system in the southeastern USA. European Journal of Agronomy 57:62-70.

Freitas, T. M. S. 2003. Dinâmica da produção de forragem, comportamento ingestivo e produção de ovelhas Ile de France em pastagem de azevém anual (Lolium multiflorum Lam.) em resposta a doses de nitrogênio. Dissertação (M.Sc.). Universidade Federal do Rio Grande do Sul, Porto Alegre.

Freitas, F. K. 2008. Produção ovina em pastagem de azevém manejada sob intensidades e métodos de pastejo em integração lavourapecuária. Tese (D.Sc.). Universidade Federal do Rio Grande do Sul, Porto Alegre.

Gastal, F. and Lemaire, G. 2015. Defoliation, shoot plasticity, sward structure and herbage utilization in pasture: Review of the underlying ecophysiological processes. Agriculture 5:1146-1171.

George, S.; Wright, D. L. and Marois, J. J. 2013. Impact of grazing on soil properties and cotton yield in an integrated crop-livestock system. Soil and Tillage Research 132:47-55.

Griffon, M. 2012. Qu'est-ce qu'une agriculture ecologiquiment intensive?, Quae, Versailles.

Hannah, L.; Ikegami, M.; Hole, D. G.; Seo, C.; Butchart, S. H. M.; Peterson, A T. and Roehrdanz, P. R. 2013. Global climate change adaptation priorities for biodiversity and food security. PLoS One $8: 1-10$.

Jose, S.; Gillespie, A. R. and Pallardy, S. G. 2004. Interspecific interactions in temperate agroforestry. Agroforestry Systems 61-62:237-255.

Kluthcousk, J. and Stone, L. F. 2003. Manejo sustentável dos solos dos Cerrados. p.61-104. In: Integração lavoura-pecuária. Embrapa, Santo Antônio de Goiás.

Kunrath, T. R.; Carvalho, P. C. F.; Cadenazzi, M.; Bredemeier, C. and Anghinoni, I. 2015. Grazing management in an integrated crop-livestock system: soybean development and grain yield. Revista Ciência Agronômica 46:645-653.

Lemaire, G.; Franzluebbers, A.; Carvalho, P. C. F. and Dedieu, B. 2014. Integrated crop-livestock systems: Strategies to achieve synergy between agricultural production and environmental quality. Agriculture Ecosystems \& Environment 190:4-8.

Lemaire, G.; Gastal, F.; Franzluebbers, A. and Chabbi, A. 2015. Grassland-Cropping Rotations: An avenue for agricultural diversification to reconcile high production with environmental quality. Environmental Management 56:1065-1077.

Lin, C. H.; McGraw, R. L.; George, M. F. and Garrett, H. E. 1999. Shade effects on forage crops with potential in temperate agroforestry practices. Agroforestry Systems 44:109-119.

Lunardi, R.; Carvalho, P. C. F.; Trein, C. R.; Costa, J. A.; Cauduro, G. F.; Barbosa, C. M. P. and Aguinaga, A. A. Q. 2008. Rendimento de soja em sistema de integração lavoura-pecuária: efeito de métodos e intensidades de pastejo. Ciência Rural 38:795-801.

Lustosa, S. B. C. 1998. Efeito do pastejo nas propriedades químicas do solo e na produção de soja e milho sobre pastagem consorciada de inverno no sistema de integração lavoura-pecuária. Dissertação (M.Sc.). Universidade Federal de Paraná, Curitiba.
Macari, S.; Carvalho, P. C. F.; Oliveira, L.; Devincenzi, T.; Albuquerque, C. and Moraes, A. 2011. Recria de borregas sob diferentes métodos de pastoreio em azevém anual em sucessão a lavoura. Pesquisa Agropecuária Brasileira 46:1401-1408.

Millennium Ecosystem Assessment. 2005. M. Ecosystems and human well-being: Current state and trends. Islandpress, Washington, Covelo, London. p.2-23.

Moraes, A.; Carvalho, P. C. F.; Anghinoni, I.; Lustosa, S. B. C.; Costa, S. E. V. G. A. and Kunrath, T. R. 2014. Integrated croplivestock systems in the Brazilian subtropics. European Journal of Agronomy 57:4-9.

Moraes, A.; Carvalho, P. C. F.; Lustosa, S. B.; Barro, R. S.; Piva, J. T.; Porfírio-da-Silva, V. and Lang, C. R. 2012. Sistemas integrados de produção agrícola e pecuária: caminho para a intensificação sustentável. In: A responsabilidade social da pesquisa agrícola. Proceedings... Fertbio, Maceió, Alagoas.

Moraine, M.; Duru, M. and Therond, O. 2017. A social-ecological framework for analyzing and designing integrated crop-livestock systems from farm to territory levels. Renewable Agriculture and Food Systems 32:43-56.

Nair, P. K. R. 1993. Introduction to agroforestry. Kluwer Academic Publishers, Dordrecht. 499p.

Nunes, P. A. A. 2016. Como a intensidade de pastejo determina a heterogeneidade espacial da vegetação e suas implicações em um sistema integrado de produção agropecuária. Dissertação (M.Sc.). Universidade Federal de Rio Grande do Sul, Porto Alegre.

Ong, C. K. and Leakey, R. R. B. 1999. Why tree-crop interactions in agroforestry appear at odds with tree-grass interactions in tropical savannahs. Agroforestry Systems 45:109-129.

Rota, A. and Sperandini, S. 2011. Integrated crop-livestock farming systems. Livestock Thematic Paper IFAD 1-8.

Ruedell, J. 1996. Plantio direto na região de Cruz Alta. FUNDACEP, Cruz Alta.

Russelle, M. P.; Entz, M. H. and Franzluebbers, A. J. 2007. Reconsidering integrated crop-livestock systems in North America. Agronomy Journal 99:325-334.

Ryschawy, J.; Joannon, A. and Gibon, A. 2014. L'exploitation de polyculture-élevage: définitions et questions de recherche. Une revue. Cahiers Agricultures 23:346-356.

Sandini, I. E.; Moraes, A.; Pelissari, A.; Neumann, M.; Falbo, M. K. and Novakowiski, J. H. 2011. Efeito residual do nitrogênio na cultura do milho no sistema de produção integração lavourapecuária. Ciência Rural 41:1315-1322.

Sartor, L. R.; Assmann, A. L.; Assmann, T. S.; Bigolin, P. E.; Miyazawa, M. and Carvalho, P. C. F. 2012. Effect of swine residue rates on corn, common bean, soybean and wheat yield. Revista Brasileira de Ciência do Solo 36:661-669.

Silva, H. A.; Moraes, A.; Carvalho, P. C. F.; Fonseca, A. F. and Dias, C. T. S. 2012. Maize and soybeans production in integrated system under no-tillage with different pasture combinations and animal categories. Revista Ciência Agronômica 43:757-765.

Silva, M. R. 2016. Aplicação superficial de calcário e gesso em sistemas integrados de produção agropecuária. Tese (D.Sc.). Universidade Federal de Paraná, Curitiba.

Silva, S. C. and Pedreira, C. G. S. 1997. Princípios de ecologia aplicados ao manejo da pastagem. p.1-62. In: Simpósio sobre Ecossistemas de Pastagens. UNESP, Jaboticabal.

Silveira, E. R.; Pelissari, A.; De Moraes, A.; Von Linsingen Piazzetta, H.; Lang, C. R. and Carvalho, P. C. F. 2012. Intensidade de pastejo e adubação nitrogenada na massa seca de aveia e produtividade do milho na integração lavoura-pecuária. Semina: Ciências Agrárias 33:1323-1332

Siqueira Jr., L. A. 2005. Alterações de características do solo na implantação de um sistema de integração agricultura-pecuária 
leiteira. Dissertação (M.Sc.). Universidade Federal do Paraná, Curitiba.

Soussana, J.-F. and Lemaire, G. 2014. Coupling carbon and nitrogen cycles for environmentally sustainable intensification of grasslands and crop-livestock systems. Agriculture, Ecosystems \& Environment 190:9-17.

Stoate, C.; Boatman, N.; Borralho, R.; Carvalho, C. R.; Snoo, G. R. and Eden, P. 2001. Ecological impacts of arable intensification in Europe. Journal of Environmental Management 63:337-365.

Subbarao, G. V.; Nakahara, K.,; Ishikawa, T.; Ono, H.; Yoshida, M.; Yoshihashi, T.; Zhu, Y. and Zakir, H. A. K. M. 2013. Deshpande, S. P.; Hash, C. T.; Sahrawat, K. L. Biological nitrification inhibition (BNI) activity in sorghum and its characterization. Plant and Soil 366:243-259.
Torquebiau, E. 2000. A renewed perspective on agroforestry concepts and classification. Comptes Rendus de l'Academie des Sciences. Series III Sciences de la Vie, Montrouge 323:1009-1017.

Tracy, B. F. and Zhang, Y. 2008. Soil compaction, corn yield response, and soil nutrient pool dynamics within an integrated crop-livestock system in Illinois. Crop Science 48:1211.

Wilson, J. R. and Ludlow, M. M. 1990. The environment and potential growth of herbage under plantation. p.10-24. In: Proceedings of the 32nd Workshop, Sanur Beach, Bali-Indonesia. Australian Center for International Agricultural Research, Sanur Beach.

Zimmer, A. H.; Macedo, M. C. M.; Kichel, A. N. and Euclides, V. P. B. 2004. Integrated agropastoral production systems. p.253-290. In: Agropastoral Systems for the Tropical Savannas of Latin America. Guimarães, E. P.; Sanz, J. I.; Rao, I. M.; Amézquita, M. C.; Amézquita, E. and Thomas, R. J., eds. Colombia, CIAT. 